Check for updates

Cite this: Mater. Adv., 2022, 3, 254

Received 6th September 2021, Accepted 22nd September 2021

DOI: $10.1039 / \mathrm{d} 1 \mathrm{ma} 00810 \mathrm{~b}$

rsc.li/materials-advances

\section{Fabrication of flower-like bismuth vanadate hierarchical spheres for an improved supercapacitor efficiency}

\author{
Subramanian Balachandran, (D) abc Rajan Karthikeyan, (D) de Kumaravel Jeeva Jothi, ${ }^{\dagger}$ \\ Veerappan Manimuthu, ${ }^{9}$ Natarajan Prakash, ${ }^{\text {h }}$ Zheming Chen, ${ }^{a}$ Tongxiang Liang, (D) d \\ Chengzhi Hu, (D) *c Feng Wang (D)*a and Mingshu Yang ${ }^{*^{a}}$
}

\begin{abstract}
A cost-effective and simple method has been developed for the preparation of flower-like hierarchical spheres of semiconductor oxide materials. Efficient self-assembly of $\mathrm{BiVO}_{4}$ flower-like hierarchical spheres was performed via a simple hydrothermal method, followed by calcination at $500{ }^{\circ} \mathrm{C}$. X-ray diffraction (XRD) studies distinguished diffraction planes of the monoclinic $\mathrm{BiVO}_{4}$ phase, which was further confirmed by field emission scanning electron microscopy (FESEM) analysis. The electronic and optical properties of $\mathrm{BiVO}_{4}$ were studied via X-ray photoelectron spectroscopy (XPS) and UV-visible spectroscopy. XPS analysis confirmed the binding energy relations and the formation of $\mathrm{BiVO}_{4}$, and also an increase in the $\mathrm{Bi}-\mathrm{O}, \mathrm{V}-\mathrm{O}$ bond strengths in $\mathrm{BiVO}_{4}$. The remarkable efficiency of pseudocapacitor electrode materials depends on the consistent fabrication of nano architectures. The carbon-free $\mathrm{BiVO}_{4}$ electrodes showed a higher specific capacitance of $1203 \mathrm{~F} \mathrm{~g}^{-1}$ at $2 \mathrm{~A} \mathrm{~g}^{-1}$, without detectable degradation after 2000 cycles and a beneficial cycling stability was achieved because of the electrochemical activity of the distinctive porous hierarchical architecture. Our synthetic method suggests a simple procedure for the design and fabrication of bismuth vanadate hierarchical nano architectures, encouraging electrochemical energy storage. These nanocomposites could be utilized as anode materials in lithiumion batteries.
\end{abstract}

${ }^{a}$ Beijing National Laboratory for Molecular Sciences, Key Laboratory of Engineering Plastics, Institute of Chemistry, Chinese Academy of Sciences, Zhongguancun North First Street 2, Beijing 100190, P. R. China. E-mail: yms@iccas.ac.cn, wangfeng0822@iccas.ac.cn, hucz@sustech.edu.cn; Fax: +86-10-62561945; Tel: $+86-10-62561945$

${ }^{b}$ Center for Nanoscience and Technology, Chennai Institute of Technology, Sarathy Nagar, Kundrathur, Chennai 600069, Tami Nadu, India

${ }^{c}$ Department of Mechanical and Energy Engineering, Southern University of Science and Technology, Shenzhen, Guangdong, China

${ }^{d}$ Engineering Research Centre for Hydrogen Energy Materials and Devices, College of Rare Earths (CORE), Jiangxi University of Science and Technology, Ganzhou 341000, Jiangxi, China

${ }^{e}$ Division of Physical Sciences, Department of Science and Humanities, Saveetha School of Engineering, Saveetha Institute of Medical and Technical Sciences, Saveetha University, Thanadalam 600056, Tamil Nadu, India

${ }^{f}$ Central Institute of Plastics Engineering and Technology, Plastics Technology Guindy Chennai, Chennai 600032, Tami Nadu, India

${ }^{g}$ Department of Electrical and Electronic Engineering Southern University of Science and Technology Nanshan District, Shenzhen, Guangdong 518055, P. R. China

${ }^{h}$ Division of Chemistry, Department of Science and Humanities, Saveetha School of Engineering, Saveetha Institute of Medical and Technical Sciences, Saveetha University, Thanadalam 600056, Tamil Nadu, India

\section{Introduction}

The fabrication of 3D micro/nanostructures with hierarchical or complex structures in recent years have gained considerable recognition for their popularity in numerous fields, ${ }^{1-3}$ such as medicine ${ }^{4-8}$ microfluidics, ${ }^{9,10}$ electronics, ${ }^{11-13}$ optics, ${ }^{14-16}$ and chemistry. ${ }^{17-19}$ Encouraged by the great multiplicity of fascinating properties, researchers have carried out experiments to find out new functionalities and used various methods for preparing multiscale hierarchical surfaces or three-dimensional (3D) structures. The inorganic nanomaterials show large numbers of size and shapedependent properties. Therefore, synthesizing nanomaterials with controlled shape, size, dimension and structure has unique implications. ${ }^{20,21}$ Extensive examination of hierarchical nanostructures made from nanocrystals, such as nanoparticles, ${ }^{22}$ nanowires/ belts/rods ${ }^{23,24}$ and nanoplates/sheets/disks, ${ }^{25,26}$ showing exclusive physical and chemical properties different from that of the nanocrystals. Numerous hierarchical nanostructures with metals, ${ }^{27}$ oxides, ${ }^{28,29}$ sulfides, ${ }^{30-34}$ hydrates, ${ }^{35}$ etc. ${ }^{36-38}$ have been fabricated for multiple applications. Therefore, discovering and exploring new nanoarchitectures or hierarchical nanostructures are promising for next-generation devices. Besides their abilities and properties, 
addressing fundamental science questions and their utilization in technical applications is much needed.

The supercapacitors play a important role in next-generation energy storage systems, because of its attractiveness as a source of energy. In contrast to batteries, they are high-power storage devices, maintenance-free, thus providing a long life-cycle with rapid charge-discharge. They require a simple charging system without a memory effect, which is more secure than the conventional storage devices. Physical energy storage is advantageous over chemical energy storage for operational safety with more extended periods. Thus, supercapacitors satisfy longer lifecycles because of their high charging and discharging rates. Supercapacitors have a better reputation mainly to electric vehicles and their remarkable potential to facilitate future journeys. In the recent times, there have been extensive efforts to develop novel electrode materials with higher capacity, unique and more compatible miniature designs. More advances in optimizing electrode materials such as surface morphology, crystallinity, porosity, surface chemical reactivity, capacitance, and storage efficiency play an important role in deciding the supercapacitor quality, which may help to maximize supercapacitors' widespread potential as power storage devices. ${ }^{39,40}$ Pseudo-capacitors are excellent candidates to solve the efficiency difference between batteries and supercapacitors.

To overcome the above-mentioned issues, the $\mathrm{BiVO}_{4}$ ternary oxide semiconductor is drawing attention due to its superior attributes such as nontoxicity, solar light utilization for water splitting, ${ }^{4-44}$ toxic chemical degradation, ${ }^{45-50}$ and high stability and low bandgap $(2.4 \mathrm{eV})$ in nature. However, the photoinduced $\mathrm{BiVO}_{4}$ charge carriers (electron and holes) can easily recombine, leading to poor photocatalytic efficiency. ${ }^{51-53} \mathrm{BiVO}_{4}$ has three stable crystalline forms: namely the monoclinic scheelite structure $\left(\mathrm{ms}^{-} \mathrm{BiVO}_{4}\right)$, tetragonal zircon $\left(\mathrm{tz}-\mathrm{BiVO}_{4}\right)$, and tetragonal scheelite $\left(\mathrm{ts}-\mathrm{BiVO}_{4}\right)$. Among them, ms- $\mathrm{BiVO}_{4}$ exhibits better electron conductivity ${ }^{54}$ and light-induced catalytic activity relative to other forms. The band structure of BiVO $_{4}$ with conduction and valence bands comprising of $\mathrm{V}$ $3 \mathrm{~d}, \mathrm{Bi} 6 \mathrm{~s}$, and $\mathrm{O} 2 \mathrm{p}$ orbitals are characteristic nature of $\mathrm{BiVO}_{4}$. Hence, numerous researchers focus on developing visible lightactive photocatalysts using $\mathrm{BiVO}_{4}{ }^{55-57}$ compared to their energy storage-related applications. The list of previous $\mathrm{BiVO}_{4}$-based energy storage works is limited, and their specific capacitance results are summarized in Table 1.

According to our literature survey, in almost all of the $\mathrm{BiVO}_{4}^{-}$ based energy storage devices, ${ }^{58-66}$ the materials were fabricated by a hydro/solvothermal process, and the temperature ranged from $120{ }^{\circ} \mathrm{C}$ to $220{ }^{\circ} \mathrm{C}$. The source materials of bismuth nitrate pentahydrate and ammonium vanadate are common in the presence of nitric acid solvent. However, the use of graphene/ reduced graphene oxide or other conductive materials in support of $\mathrm{BiVO}_{4}$ is dominant in improving the conductivity of the electrodes for supercapacitor applications. Up until this point, only few studies have been accounted for $\mathrm{BiVO}_{4}$ as an anode material for supercapacitors. In recent times, it has been proven that $\mathrm{BiVO}_{4}$ can improve the performance of supercapacitors as an electrode material due to its admirable physicochemical behavior and high stability. This study focuses on flower-shaped $\mathrm{BiVO}_{4}$ for supercapacitor application without addition of any noble metals (such as $\mathrm{Au}$ and $\mathrm{Ag}$ ) or carbon materials (such as RGO, SWCNT, and graphene) etc. The addition of noble metals, graphene, reduced graphene oxides are more expensive. Controlling only the shape of $\mathrm{BIVO}_{4}$ may influence the higher activity. The overall approach result with the nanocomposites of different morphologies ranging from particles to nanorods. The morphological and surface area of the $\mathrm{BiVO}_{4}$ material is essential in addition to its structural control $\left(\mathrm{m}-\mathrm{BiVO}_{4}\right)$. The highest specific capacitance of $479 \mathrm{~F} \mathrm{~g}^{-1}$ was achieved by Deng et al. with the current density of $5 \mathrm{~A} \mathrm{~g}^{-1}$.

Table 1 List of $\mathrm{BiVO}_{4}$ literatures on supercapacitor applications

\begin{tabular}{|c|c|c|c|c|c|c|}
\hline \multicolumn{2}{|c|}{ No. Source materials } & \multirow{2}{*}{$\begin{array}{l}\text { Synthesized } \\
\text { product }\end{array}$} & \multirow{2}{*}{$\begin{array}{l}\text { Method, temperature } \\
\text { \& time } \\
\text { Hydrothermal } 180^{\circ} \mathrm{C}\end{array}$} & \multirow{2}{*}{$\begin{array}{l}\begin{array}{l}\text { Specific } \\
\text { capacitance }\end{array} \\
\begin{array}{l}479 \mathrm{~F} \mathrm{~g}^{-1} \text { at } \\
5 \mathrm{~A} \mathrm{~g}^{-1}\end{array}\end{array}$} & \multirow{2}{*}{$\begin{array}{l}\begin{array}{l}\text { Structure \& } \\
\text { morphology }\end{array} \\
\begin{array}{l}\text { Free standing } \\
\text { composites }\end{array}\end{array}$} & \multirow{2}{*}{$\begin{array}{l}\text { Ref. } \\
\begin{array}{l}\text { Deng et al., } \\
2018^{60}\end{array}\end{array}$} \\
\hline 1 & Graphene oxide, $\mathrm{Bi}\left(\mathrm{NO}_{3}\right)_{3} \cdot 5 \mathrm{H}_{2} \mathrm{O}, \mathrm{NH}_{4} \mathrm{VO}_{3}$ & & & & & \\
\hline 2 & $\mathrm{Bi}(\mathrm{NO} 3) 3 \cdot 5 \mathrm{H} 2 \mathrm{O}, \mathrm{NH}_{4} \mathrm{VO}_{3}$, Graphene oxide, & $\mathrm{rGO} / \mathrm{BiVO}_{4}$ & Hydrothermal $180^{\circ} \mathrm{C}-24 \mathrm{~h}$ & $\begin{array}{l}94.83 \mathrm{~F} \mathrm{~g} \mathrm{~g}^{-1} \\
\text { at } 1.4 \mathrm{~A} \mathrm{~g}^{-1}\end{array}$ & Rod-like structures & $\begin{array}{l}\text { Patil et al., } \\
2016^{62}\end{array}$ \\
\hline 3 & $\begin{array}{l}\mathrm{Bi}\left(\mathrm{NO}_{3}\right)_{3} \cdot 5 \mathrm{H}_{2} \mathrm{O}, \mathrm{Na}_{2} \mathrm{VO}_{3}, \mathrm{NaOH} \text {, Sodium } \\
\text { dodecyl benzene sulfonate (SDS), GO }\end{array}$ & $\mathrm{rGO} / \mathrm{BiVO}_{4}$ & Hydrothermal $200{ }^{\circ} \mathrm{C}-1.5 \mathrm{~h}$ & $\begin{array}{l}400 \mathrm{~F} \mathrm{~g}^{-1} \text { at } \\
5 \mathrm{mV} \mathrm{s}^{-1}\end{array}$ & $\begin{array}{l}\mathrm{m}^{-\mathrm{BiVO}_{4}} \text { nano- } \\
\text { particles on/rGO }\end{array}$ & $\begin{array}{l}\text { Dutta et al. } \\
2018^{59}\end{array}$ \\
\hline 4 & $\begin{array}{l}\mathrm{Bi}\left(\mathrm{NO}_{3}\right)_{3} \cdot 5 \mathrm{H}_{2} \mathrm{O}, \mathrm{NH}_{4} \mathrm{VO}_{3} \text {, Sodium dodecyl } \\
\text { benzene sulfonate (SDS) }\end{array}$ & $\mathrm{SWCNT} \mathrm{BiVO}_{4}$ & Hydrothermal $160{ }^{\circ} \mathrm{C}-18 \mathrm{~h}$ & $395 \mathrm{~F} \mathrm{~g}^{-1}$ & $\begin{array}{l}\text { m-BiVO } \\
\text { particles on } / \text { SWCNT }\end{array}$ & $\begin{array}{l}\text { Khan et al. } \\
2014^{61}\end{array}$ \\
\hline 5 & $\begin{array}{l}\text { Bismuth oxyiodide electrodeposited on FTO, } \\
\text { annealed at } 450{ }^{\circ} \mathrm{C} \text { in vanadyl acetylacetonate }\end{array}$ & $\mathrm{rGO} / \mathrm{BiVO}_{4}$ & Annealed at $450{ }^{\circ} \mathrm{C}$ & $\begin{array}{l}141.8 \mathrm{~F} \mathrm{~g}^{-1} \\
\text { at } 0.2 \mathrm{~A} \mathrm{~g}^{-1}\end{array}$ & $\mathrm{~m}^{-\mathrm{BiVO}_{4}} / \mathrm{rGO}$ & $\begin{array}{l}\text { Roy et al., } \\
2020^{63}\end{array}$ \\
\hline 6 & $\mathrm{Bi}\left(\mathrm{NO}_{3}\right)_{3} \cdot 5 \mathrm{H}_{2} \mathrm{O}, \mathrm{NH}_{4} \mathrm{VO}_{3}$, Graphene oxide, & $\mathrm{rGO} / \mathrm{BiVO}_{4}$ & Hydrothermal $180^{\circ} \mathrm{C}-24 \mathrm{~h}$ & $\begin{array}{l}484 \mathrm{~F} \mathrm{~g} \mathrm{~g}^{-1} \text { at } \\
5 \mathrm{mV} \mathrm{s}^{-1}\end{array}$ & $\begin{array}{l}\mathrm{BiVO}_{4} / \mathrm{rGO} \\
\text { nanocomposites }\end{array}$ & $\begin{array}{l}\text { Sengottayan } \\
\text { et al., } 2019^{64}\end{array}$ \\
\hline 7 & $\begin{array}{l}\mathrm{Bi}\left(\mathrm{NO}_{3}\right)_{3} \cdot 5 \mathrm{H}_{2} \mathrm{O}, \mathrm{NH}_{4} \mathrm{VO}_{3} \text {, Polymerization: } \\
\text { aniline, } \mathrm{H}_{2} \mathrm{SO}_{4} \text {, potassium peroxoxdisulphate }\end{array}$ & $\mathrm{BiVO}_{4} / \mathrm{PANI}$ & $\begin{array}{l}\text { Solution synthesis at } 120{ }^{\circ} \mathrm{C}- \\
12 \mathrm{~h} \text { annealed at } 400{ }^{\circ} \mathrm{C}-3 \mathrm{~h}\end{array}$ & $\begin{array}{l}701 \mathrm{~F} \mathrm{~g}^{-1} \text { at } \\
1 \mathrm{~A} \mathrm{~g}^{-1}\end{array}$ & $\begin{array}{l}\mathrm{BiVO}_{4} / \mathrm{PANI} \\
\text { nanocomposites }\end{array}$ & $\begin{array}{l}\text { Srinivasan } \\
\text { et al., } 2020^{65}\end{array}$ \\
\hline 8 & $\mathrm{Bi}\left(\mathrm{NO}_{3}\right)_{3} \cdot 5 \mathrm{H}_{2} \mathrm{O}, \mathrm{NH}_{4} \mathrm{VO}_{3}, \mathrm{AgNO}_{3}, \mathrm{NaBH}_{4}$ & $\mathrm{BiVO}_{4}: \mathrm{Ag}$ & Solution synthesis & $109 \mathrm{~F} \mathrm{~g}^{-1}$ at & $\begin{array}{l}\mathrm{BiVO}_{4} \text { nanosheets/Ag } \\
\text { nanoparticles hybrid }\end{array}$ & $\begin{array}{l}\text { Zhang et al. } \\
2017^{66}\end{array}$ \\
\hline 9 & $\begin{array}{l}\mathrm{Bi}\left(\mathrm{NO}_{3}\right)_{3} \cdot 5 \mathrm{H}_{2} \mathrm{O}, \mathrm{NH}_{4} \mathrm{VO}_{3} \text {, Graphene oxide, } \\
\text { sodium dodecyl benzene sulfonate (SDS) }\end{array}$ & $\begin{array}{l}{\mathrm{PRGO} / \mathrm{BiVO}_{4}} \\
\text { for Li-Ion } \\
\text { batteries }\end{array}$ & Hydrothermal $180^{\circ} \mathrm{C}-12 \mathrm{~h}$ & $\begin{array}{l}160 \mathrm{~F} \mathrm{~g}^{-1} \text { at } \\
0.9 \mathrm{~A} \mathrm{~g}^{-1}\end{array}$ & $\begin{array}{l}\text { Nanorods of } \mathrm{BiVO}_{4} / \\
\text { PRGO }\end{array}$ & $2018^{58}$ \\
\hline 10 & $\mathrm{Bi}\left(\mathrm{NO}_{3}\right)_{3} \cdot 5 \mathrm{H}_{2} \mathrm{O}, \mathrm{NH}_{4} \mathrm{VO}_{3}$ & $\mathrm{BiVO}_{4}$ & Hydrothermal $220^{\circ} \mathrm{C}-24 \mathrm{~h}$ & $\begin{array}{l}1203 \mathrm{~F} \mathrm{~g}^{-1} \\
\text { at } 2 \mathrm{~A} \mathrm{~g}^{-1}\end{array}$ & $\begin{array}{l}\text { Nanosheets } \\
\text { composed hier- } \\
\text { archical m-BiVO }\end{array}$ & This work \\
\hline
\end{tabular}


Here, graphene was used as the conducting support and the effect of the structural and morphological features of $\mathrm{BiVO}_{4}$ was not explicated towards its specific capacitance. ${ }^{60}$

Thus, we present a facile and robust one-step ${ }^{67-69}$ carbonfree synthesis of $\mathrm{BiVO}_{4}$ hierarchical structures via a hydrothermal method and achieved the highest specific capacitance for supercapacitor applications. This surfactant-free process approach is energy-efficient and reliable for structure and morphological control. The detailed results and discussions are as follows.

\section{Experimental section}

\section{Materials and methods}

Bismuth nitrate pentahydrate $\left[\mathrm{Bi}\left(\mathrm{NO}_{3}\right)_{3} \cdot 5 \mathrm{H}_{2} \mathrm{O}\right.$, purity of $98 \%$ ] and ammonium metavanadate $\left(\mathrm{NH}_{4} \mathrm{VO}_{3}\right.$, purity of $\left.99.0 \%\right)$ were purchased from Sigma-Aldrich. Solvents of $1 \mathrm{M} \mathrm{HNO}_{3}(70 \%$ pure), sodium hydroxide and ethanol were purchased from Merck. All the chemical products were of analytical grade and used without further purification. All the tests were done using deionized (DI) water.

The hydrothermal method was used to synthesize $\mathrm{BiVO}_{4}$. First, $30 \mathrm{~mL}$ of $\mathrm{NH}_{4} \mathrm{VO}_{3}(5 \mathrm{mmol})$ was preheated to $75{ }^{\circ} \mathrm{C}$ and then $30 \mathrm{~mL}$ of $\mathrm{Bi}\left(\mathrm{NO}_{3}\right)_{3} \cdot 5 \mathrm{H}_{2} \mathrm{O}(5 \mathrm{mmol})$ aqueous suspension was added and stirred for 15 min until it turns into light-yellow solution. Then $\mathrm{pH}$ of the solution mixture was adjusted to 7 with dilute $\mathrm{NaOH}$. Further, stirring was carried out for $30 \mathrm{~min}$ before transferring into a $100 \mathrm{~mL}$ volume Teflon-lined stainless autoclave and kept at $220{ }^{\circ} \mathrm{C}$ for $24 \mathrm{~h}$. After the reaction, the products were washed with DI water, absolute ethanol, acetone and centrifuged. This process was repeated five times to obtain pure precipitate without any impurities and unreacted products. The dried sample was calcined at $500{ }^{\circ} \mathrm{C}$ in an ambient air atmosphere for $5 \mathrm{~h}$ to get the $\mathrm{BiVO}_{4}$ nanomaterial.

\section{Characterizations}

A variety of analytical measurement techniques were utilized to characterize the as-prepared $\mathrm{BiVO}_{4}$ material. A field emission scanning electron microscope (FESEM, Hitachi S-4100) was used to visualize the morphology of the material. Before the measurement, the sample was prepared on a carbon tape platform and coated with platinum by a magnetron sputter for $5 \mathrm{~min}$. Morphological and microstructural behaviors of BiVO $_{4}$ nanosheets were studied via high-resolution transmission electron microscopy (TEM, JEM-2100, JEOL, Japan), X-ray diffraction (XRD, Japan, Rigaku D/max-2500) and UV-visible DRS (TU-1901, Pgener al) spectrometer. The X-ray photoelectron spectra (XPS) were collected on an ESCA Lab 220i-XL, VG Scientific X-ray photoelectron spectrometer, using MgK $\alpha$ X-ray as an excitation source. The base pressure was about $3 \times 10^{-9}$ mbar.

\section{Electrode preparation}

The electrochemical behaviors of the electrodes were analyzed by utilizing a three-electrode system. Here, the three electrodes used were a Pt wire (as the counter electrode), $\mathrm{Ag} / \mathrm{AgCl}$ electrode (as the reference electrode) and the as-synthesized $\mathrm{BiVO}_{4}$ hierarchical spheres (1 $\mathrm{mg}$ ) (as the working electrode). First, $\mathrm{BiVO}_{4}$ was dispersed in distilled water $(1 \mathrm{~mL})$ under sonication for $\sim 60 \mathrm{~min}$, and $5 \mu \mathrm{L}$ of the dispersion solution was drop-cast onto the surface of the glassy carbon (GCE) working electrode before CV and GCD measurements. The GCE was pre-treated with acetone, absolute ethanol and deionized water for $15 \mathrm{~min}$ to get the clean surface. $2 \mathrm{M} \mathrm{KOH}$ was used as the electrolyte. Working electrodes were prepared separately by blending $95 \%$ of the as-synthesized $\mathrm{BiVO}_{4}$, along with a $5 \%$ Nafion ${ }^{\circledR}$ perfluorinated resin solution $(0.5 \% \mathrm{w} / \mathrm{v}, 5 \mu \mathrm{L})$ as a binder in ethanol solvent. After coating the as-prepared slurry on GCE, it was dried at $80{ }^{\circ} \mathrm{C}$ for $30 \mathrm{~min}$ and then the electrode weight was measured to figure out the quantity of as-synthesized materials on the GCE.

\section{Results and discussion}

The structural behavior of the as-synthesized sample was studied on a powder X-ray diffractometer, and the results are shown in Fig. 1. The diffraction planes from XRD patterns wellmatched with the corresponding monoclinic $\mathrm{BiVO}_{4}$ (JCPDS card no. $75-1866) .^{70}$ The peak positions of $15.13^{\circ}, 19^{\circ}, 28.97^{\circ}$, $30.55^{\circ}, 34.51^{\circ}, 35.24^{\circ}, 40.28^{\circ}, 42.49^{\circ}, 46.09^{\circ}, 46.75^{\circ}, 47.31^{\circ}$, $50.33^{\circ}, 53.32^{\circ}, 55.93^{\circ}, 57.93^{\circ}, 58.31^{\circ}, 59.71^{\circ}, 63.58^{\circ}, 66.23^{\circ}$, $69.72^{\circ}, 72.78^{\circ}, 74.83^{\circ}$ and $76.72^{\circ}$ are belong to (002), (011), (112), (004), (200), (020), (121), (015), (123), (204), (024), (220), (116), (215), (107), (303), (026), (008), (134), (127), (400), (028) and (136) reflection planes, respectively. The clear matching of planes without any peak position shift suggests that the assynthesized $\mathrm{BiVO}_{4}$ phase is of high purity and free from any other trace intermediates. ${ }^{71}$ The intense sharp peaks reveal the highly crystalline nature of $\mathrm{BiVO}_{4}$ (Fig. 1).

The surface morphology of the as-prepared $\mathrm{BiVO}_{4}$ was investigated via FESEM, as shown in Fig. 2. The FESEM image (Fig. 2a) shows that the samples possessed monodispersed $\mathrm{BiVO}_{4}$ hierarchical sheet composed of architectures. These 3D

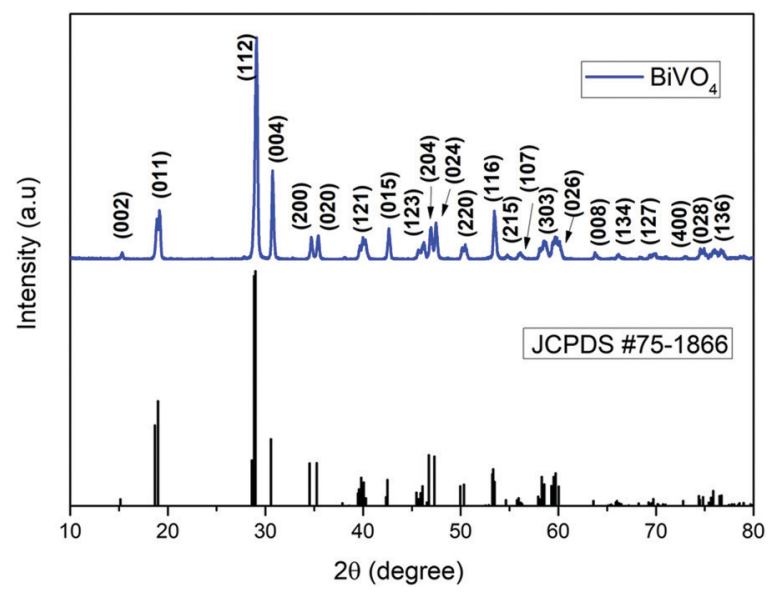

Fig. 1 X-ray diffraction pattern of $\mathrm{BiVO}_{4}$ and the corresponding reference. 

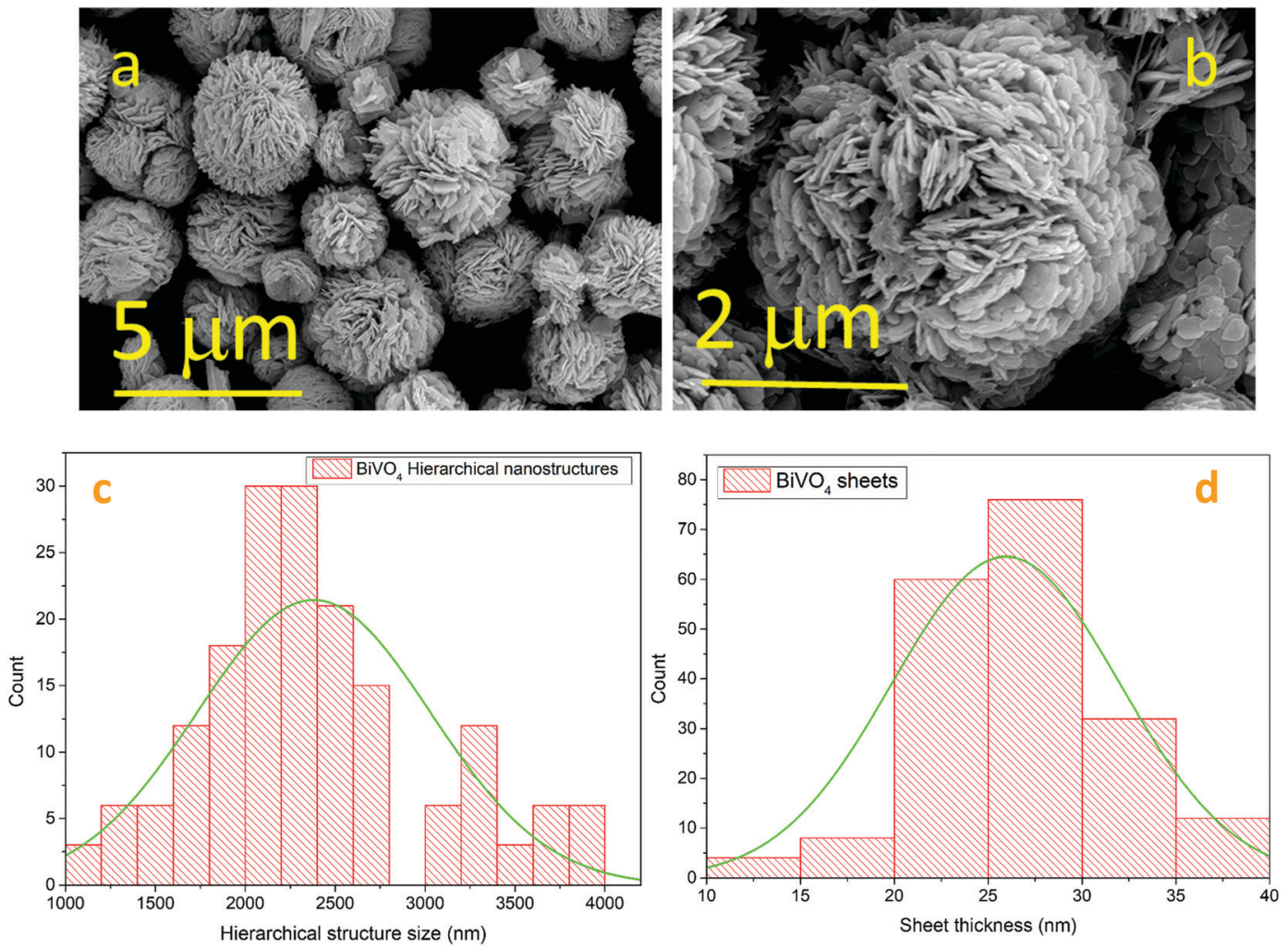

Fig. 2 FESEM images of $\mathrm{BiVO}_{4}$ (a) wide view and (b) narrow view (c) histogram of the size of hierarchical structures (d) histogram of the nanoheet thickness.

nanosheets composed of architectures expose high active surfaces at the inner core of the ball-like structure. The hydrothermal method under closed pressure for the high concentration source materials has influenced the hierarchical structural growth. It can be seen that the material is composed of a large number of nanosheets with the diameter of hierarchical spheres ranging from $2-2.5 \mu \mathrm{m}$. To validate the above range of size, we have calculated the hierarchical size distribution related histogram and the mean size was found to be $2.3 \mu \mathrm{m}$, as shown in Fig. 2c. The shape of the nanosheets was uniform, and thickness was found to be $\sim 25 \mathrm{~nm}$ from Fig. $2 \mathrm{~b}$. To elucidate the size confirmation of nanosheets, we performed the image analysis and the mean thickness of nanosheets was measured by comparing roughly 200 different nanosheets (Fig. 2d). Several tiny pores existing on the flat structures could be due to the discharge of water molecules and the structural contraction during the calcination process. ${ }^{72}$ For the hierarchical structure formation, a mechanism was proposed involving the growth of intercrossed nanosheets in the oriented attachment, followed by "Ostwald ripening." In addition, there were pore structures observed on the hierarchical spheres of $\mathrm{BiVO}_{4}$; this could be due to the results of cross-linked sheets with the exposed mesopores to microporous structures. ${ }^{34,73,74}$

The hierarchical structure formation was further studied via transmission electron microscopy (TEM). Since the particles size was in the micrometer order, during the sample preparation process smaller sized particles were deposited on the TEM sample grid, which was then analysed. Fig. 3 shows the respective TEM and high-resolution TEM images of the $\mathrm{BiVO}_{4}$ nanostructure. From Fig. 3a, it is clear that these floral hierarchical spheres are actually madeup of several nanosheets linked with each other. The interlinking of nanosheets formed 3D hierarchical structures, which mostly diffracted the electrons in TEM. However, the high-resolution TEM image in Fig. 3c reveals lattice fringes with different grain boundaries. It could be due to the composition of multiple sheets. The corresponding Fast Fourier Transform (FFT) patterns were used to measure the interplanar distances of $0.314 \mathrm{~nm}$ and $0.293 \mathrm{~nm}$. These lattice fringes were related to the (112) and (004) reflection planes in the XRD pattern of monoclinic scheelite $\mathrm{BiVO}_{4}\left(\mathrm{~m}-\mathrm{BiVO}_{4}\right){ }^{57}$ The above crystal planes were the dominant peak position of $\mathrm{m}-\mathrm{BiVO}_{4}$, which again confirmed the presence of the highly crystalline phase of pure $\mathrm{BiVO}_{4}$. The selected area electron diffraction (SAED) pattern implies the polycrystalline nature of the $\mathrm{BiVO}_{4}$ material (inset of Fig. 3c). The corresponding SAED pattern highlights the bright patterns of first order circles. Due to the polycrystalline nature of the $\mathrm{BiVO}_{4}$ material, multiple circular ring patterns of bright fringes were observed.

To confirm $\mathrm{Bi}, \mathrm{V}$, O elemental distribution on $\mathrm{BiVO}_{4}$, EDS elemental mapping was carried out via the FESEM analysis. Fig. 4 shows the elemental mapping of bismuth, vanadium, oxygen and the corresponding FESEM image. There is a homogenous distribution of $\mathrm{Bi}, \mathrm{V}$ and $\mathrm{O}$ observed with the uniform 

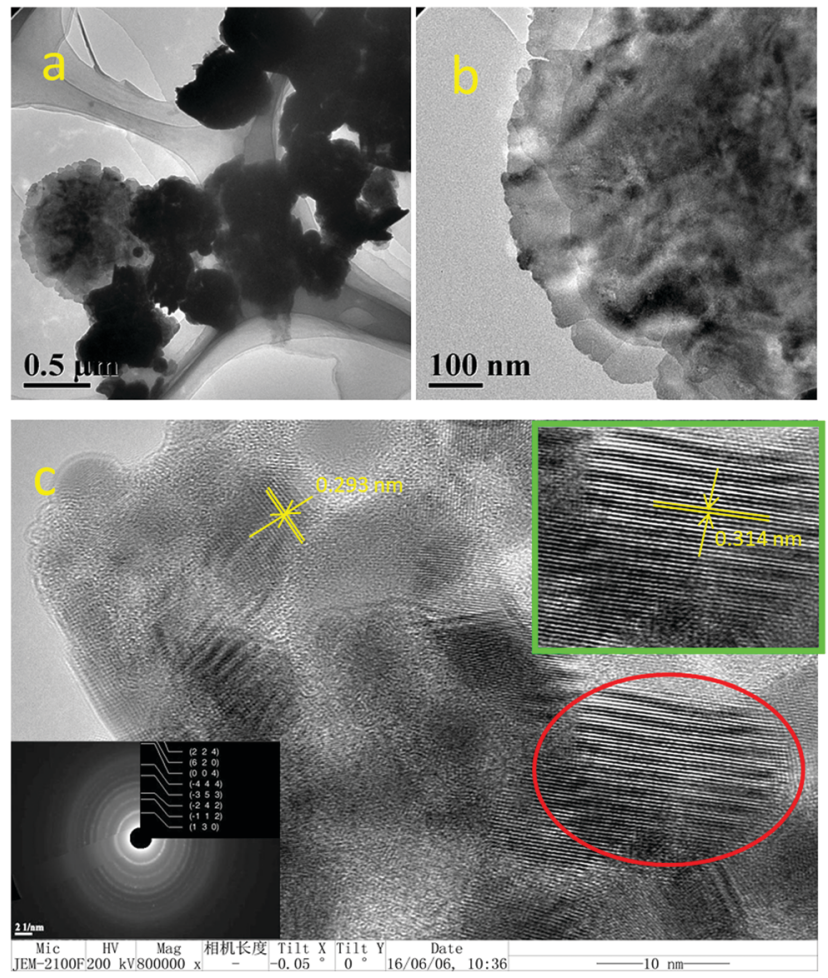

Fig. 3 TEM images of $\mathrm{BiVO}_{4}$ at (a) $500 \mathrm{~nm}$, (b) $100 \mathrm{~nm}$ scale magnifications, (c) high resolution TEM images and the corresponding lattice fringes at $10 \mathrm{~nm}$ scale with the SAED pattern.
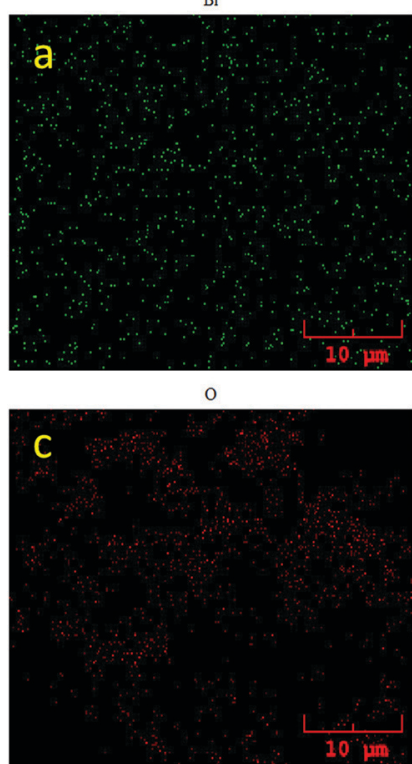

Fig. 4 EDS mapping of $\mathrm{BiVO}_{4}$ (a) $\mathrm{Bi}$ (b) $\vee$ (c) $\mathrm{O}$ elements and (d) corresponding SEM image.

patterns on Fig. $4 a-c$. Thus, the EDS mapping revealed that the material was composed of $\mathrm{Bi}, \mathrm{V}$ and $\mathrm{O}$ without any form of trace impurities.
Fig. 5 shows the XPS spectra of $\mathrm{BiVO}_{4}$. The $\mathrm{C}-\mathrm{C}$ peak position of $284.8 \mathrm{eV}$ clearly indicates that the wide spectrum of $\mathrm{BiVO}_{4}$ is a charge corrected spectrum. Also, small amounts of $\mathrm{C}-\mathrm{O}-\mathrm{C}$ and $\mathrm{O}-\mathrm{C}=\mathrm{O}$ are present at 288.9 and $286.5 \mathrm{eV}$, respectively. Fig. $5 \mathrm{a}$ is observed because of the carbon used for calibration during the measurements. Fig. $5 b, c, d$ and $f$ correspond to the spectra of $\mathrm{O} 1 \mathrm{~s}, \mathrm{Bi} 4 \mathrm{f}, \mathrm{V} 2 \mathrm{p}$ and survey spectrum, respectively. The $\mathrm{O} 1 \mathrm{~s}$ peak at $531.77 \mathrm{eV}$ is due to the adsorbed $\mathrm{H}_{2} \mathrm{O}$ or surface hydroxyl group from the atmospheric moisture. This broad peak can be fitted into two peaks at about $530.04 \mathrm{eV}$ and $533.28 \mathrm{eV}$, which is related to the existence of non-equivalent lattice oxygens (Fig. 5b). It is assigned to the lattice oxygen $\left(\mathrm{O}^{2-}\right)$ of $\mathrm{Bi}_{2} \mathrm{O}_{2}{ }^{2+}$ on the composite surface and for the surface adsorbed oxygen, respectively. The binding energy peaks at $164.4 \mathrm{eV}$ and $159.1 \mathrm{eV}$ (Fig. 5c) are related to $\mathrm{Bi} 4 \mathrm{f}_{5 / 2}$ and $\mathrm{Bi} 4 \mathrm{f}_{7 / 2}$, respectively, showing the presence of $\mathrm{Bi}^{3+}$ in the lattice of $\mathrm{Bi}_{2} \mathrm{O}_{2}{ }^{2+}$. The metallic $\mathrm{Bi}$ binding energy values of $4 \mathrm{f}_{5 / 2}$ and $\mathrm{Bi} 4 \mathrm{f}_{7 / 2}$ are $164.4 \mathrm{eV}$ and $159.1 \mathrm{eV}$, respectively. ${ }^{75}$ The symmetric peaks of $\mathrm{Bi}$ 4f are well matched with the compounds of bismuth oxides and its spinorbit component has a well seprated $\Delta$ value of $5.3 \mathrm{eV}$ equivalent to bismuth oxides.

The binding energy peaks at $524.4 \mathrm{eV}$ and $517.2 \mathrm{eV}$ belong to $\mathrm{V} 2 \mathrm{p}_{1 / 2}$ and $\mathrm{V} 2 \mathrm{p}_{3 / 2}$, respectively, which is related to the +5 oxidation state of vanadium, as shown in Fig. $5 \mathrm{~d} .{ }^{57,76}$ The deconvolution of vanadium spectrum showed a peak around $518.9 \mathrm{eV}$, which corresponded to the +4 oxidation state. Thus, although the vanadium was present in the lattice as $\mathrm{V}^{+5}$, the reduction of $\mathrm{V}^{+5}$ to $\mathrm{V}^{+4}$ could occur due to the presence of surface defects. It does influence the electronic structure of monoclinic scheelite $\mathrm{BiVO}_{4} \cdot{ }^{77}$ Besides the structural confirmation from XRD, the XPS analysis provides the required binding energies for $\mathrm{BiVO}_{4}$ formation. The XPS spectra clearly confirm the formation of $\mathrm{BiVO}_{4}$ from the elemental analysis.

UV-Diffuse reflectance spectroscopy (UV-DRS) is a suitable analysis to disclose the band structure of a semiconductor. The optical behavior of a semiconductor is determined by the photo-absorption properties also by diffusion related to its band energy structure of photo-induced electrons and holes. As displayed in Fig. 6, a pure $\mathrm{BiVO}_{4}$ sample shows high absorption till $560 \mathrm{~nm} .^{78,79}$ The transition from a valence band formed by $\mathrm{Bi} 6 \mathrm{~s}$ to a $\mathrm{CB}$ of $\mathrm{V} 3 \mathrm{~d}$ is reflected by the strong Ultraviolet to visible light absorption. ${ }^{80}$ In particular, the edge at $\sim 560 \mathrm{~nm}$ is related to the characteristic peak of $\mathrm{BiVO}_{4}$ (Fig. 6a). It shows the outstanding narrow bandgap with a high absorption coefficient. Visible light-induced photo absorption abilities are helpful to elucidate the electronic transition and excitation of more active species. The material bandgap $\left(E_{\mathrm{g}}\right)$ can be defined using eqn (1): ${ }^{71}$

$$
a h \nu=A\left(h \nu-E_{\mathrm{g}}\right)^{n}
$$

where $a$ is the absorption coefficient, $h$ is the Planck's constant, $\nu$ is the incident light frequency, $A$ is the constant and $E_{\mathrm{g}}$ is the bandgap energy. For $\mathrm{BiVO}_{4}$, the value of $n$ was found to be $1 / 2$. From the plots of $(a h \nu)^{2} v s$. photon energy $(h \nu)$ given in Fig. 6c, the bandgap $\left(E_{\mathrm{g}}\right)$ of $\mathrm{BiVO}_{4}$ was estimated to be $2.32 \mathrm{eV} .^{80}$ 

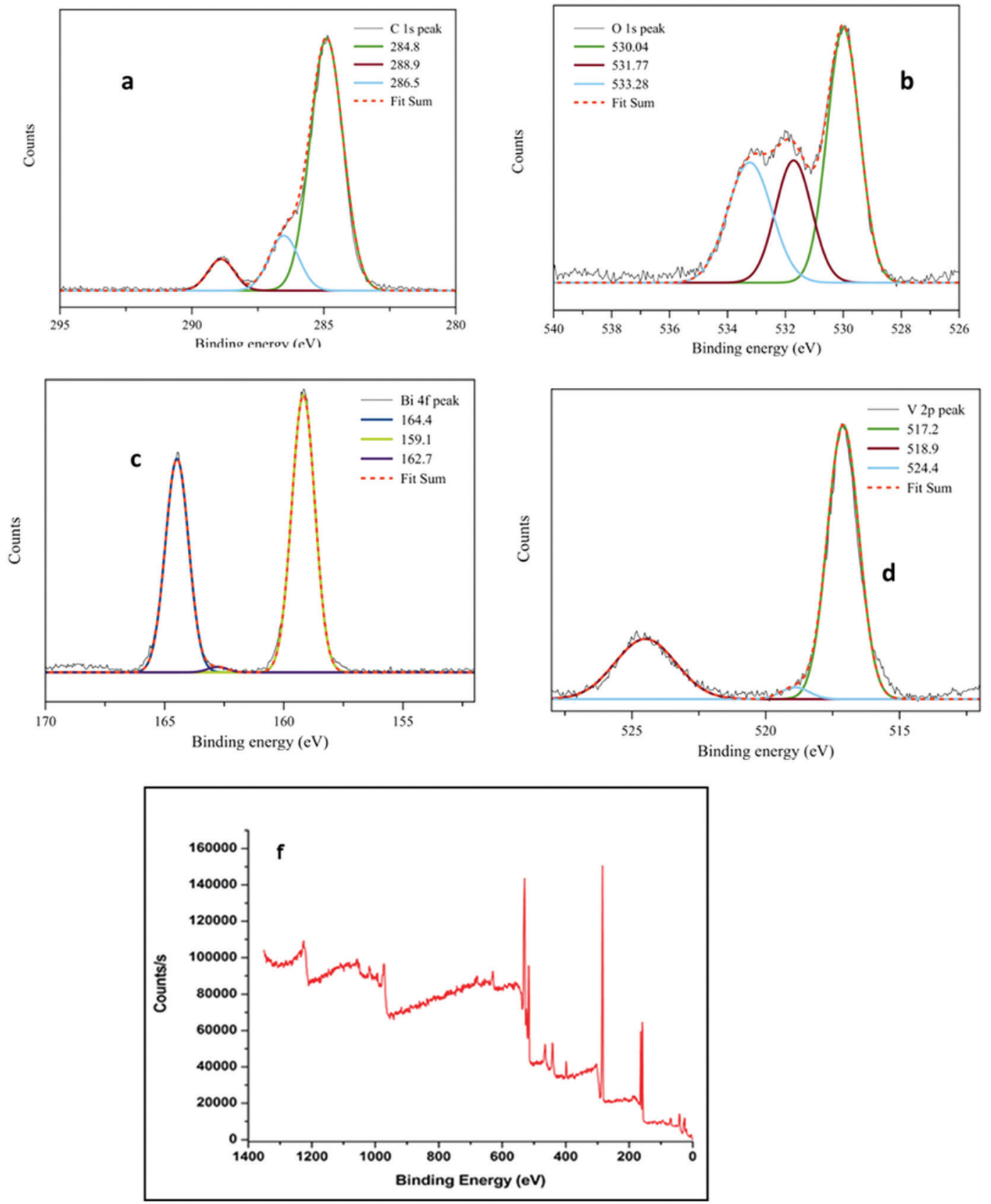

Fig. 5 High resolution XPS spectra of $\mathrm{BiVO}_{4}$ (a) C 1s, (b) $\mathrm{O} 1 \mathrm{~s}$, (c) $\mathrm{Bi} 4 \mathrm{f}$, (d) $\vee 2 \mathrm{p}$ and (f) survey spectra.

The valence band $(\mathrm{VB})$ and conduction band $(\mathrm{CB})$ edges of hierarchical $\mathrm{BiVO}_{4}$ semiconductor can be determined using eqn (2) and (3).

$$
\begin{gathered}
\mathrm{ECB}=X-E_{\mathrm{e}}-0.5 E_{\mathrm{g}} \\
\mathrm{EVB}=E_{\mathrm{g}}+\mathrm{ECB}
\end{gathered}
$$

where $X$ is the absolute electronegativity of a semiconductor (geometric mean of the absolute electronegativity of the component atoms), as determined from eqn (4):

$$
\mathrm{X}=\sqrt[(a+b+c)]{x(A)^{a} x(B)^{b} x(C)^{c}}
$$

in which $a, b$, and $c$ are the number of atoms in $A, B$, and $C$ compounds, respectively. The absolute electronegativities of $\mathrm{Bi}, \mathrm{O}$, and $\mathrm{V}$ atoms are reported to be $4.69,3.6$, and 7.54, respectively. ${ }^{81,82}$ Therefore, the absolute electronegativity of $\mathrm{BiVO}_{4}$ was calculated to be $6.16 \mathrm{eV} . E_{\mathrm{e}}$ is the energy of a free electron in the hydrogen scale (about $4.5 \mathrm{eV}$ ), and $E_{\mathrm{g}}$ is the bandgap energy of a $\mathrm{BiVO}_{4}$ semiconductor obtained from UVDRS spectra. According to the UV-vis absorption spectra, the $E_{\mathrm{g}}$ of $\mathrm{BiVO}_{4}$ was found to be about $2.32 \mathrm{eV}$. Thus, the calculated $E_{\mathrm{CB}}$ edge and $E_{\mathrm{VB}}$ edge values for $\mathrm{BiVO}_{4}$ were $0.5 \mathrm{eV}$ and $2.82 \mathrm{eV}$, respectively.

Fig. 7 shows the $\mathrm{BiVO}_{4}$ electro-chemical properties obtained using a three-electrode system in a $2.0 \mathrm{M}$ aqueous $\mathrm{KOH}$ solution. 

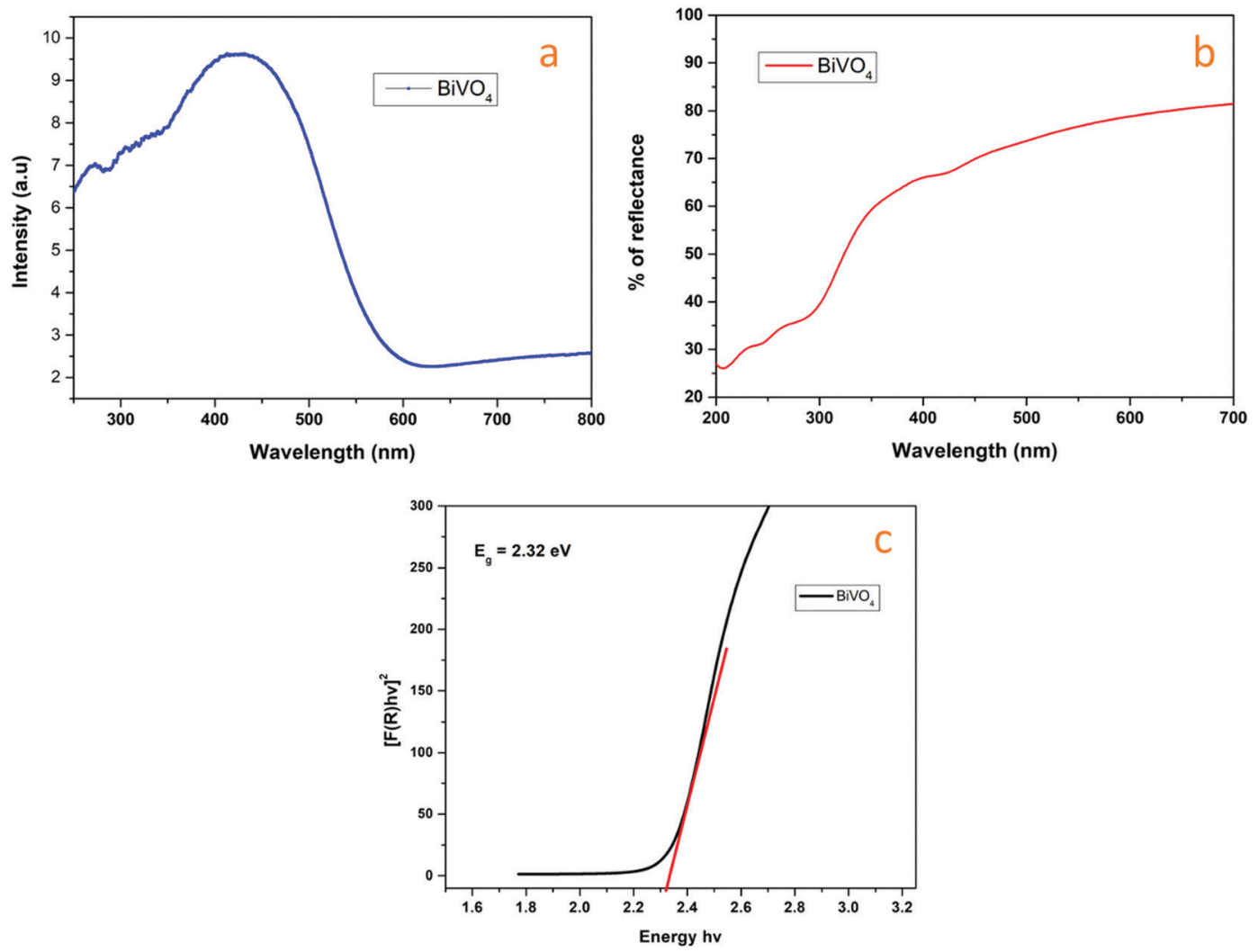

Fig. 6 UV-DRS of $\mathrm{BiVO}_{4}$ (a) absorbance and (b) reflectance spectra (c) relationship between Kubelka-Munk function vs. band gap.

The as-prepared $\mathrm{BiVO}_{4}$ showed a near-perfect rectangular CV curve that showed good capacitive behavior (Fig. 7a). The $\mathrm{BiVO}_{4}$ material showed pseudocapacitive nature with a well-resolved redox peak at $2 \mathrm{mV} \mathrm{s}^{-1}$. Even at a rate of $100 \mathrm{mV} \mathrm{s}^{-1}$, the CV curve indicated its rectangular shape, and this symmetric peak behavior represents a more significant reversibility of redox reactions. As shown in Fig. 7a, the anodic (at $-0.33,-0.49$ and $-0.65 \mathrm{~V}$ ) and cathodic peaks (at $-0.515,0.62$ and $0.78 \mathrm{~V}$ ) were observed at different potentials. ${ }^{83,84}$ The well-organized redox peaks in the $\mathrm{CV}$ curve confirm the influence of faradaic processes in the energy storage. ${ }^{85}$ The observed redox behavior was also similar to that of the $\mathrm{Bi}_{2} \mathrm{O}_{3}$ material, i.e., the reduction of $\mathrm{Bi}^{3+}$ to metallic $\mathrm{Bi}(-0.515 \mathrm{~V}$ and $0.62 \mathrm{~V})$ during the negative sweep and oxidation of metallic $\mathrm{Bi}$ to $\mathrm{Bi}^{3+}(-0.35 \mathrm{~V}$ at $2 \mathrm{mV})$ during the positive sweep. ${ }^{86}$ It is valuable to note that the peak current value increased with the scan rate. Also, small shifts were observed in the redox peak position in the positive potential directions ( $0.35 \mathrm{~V}$ to $0.11 \mathrm{~V}(100 \mathrm{mV})$ ) with no deterioration (Fig. 7b).

EIS was measured at a frequency range of $0.01 \mathrm{~Hz}$ to $100000 \mathrm{~Hz}$ at the open-circuit configuration. $\mathrm{BiVO}_{4}$ showed a semicircle shape in the observed EIS spectrum at a higher frequency with a spike in the lower frequency (Fig. 7c). The slope in the low-frequency area related to the Warburg impedance $(\mathrm{W})$ reflected the diffusion of electrolytes in host materials through pore electrodes and protons. An intersecting curve on the real part at a high frequency indicates the solution resistance $\left(R_{\mathrm{S}}\right)$, and the semicircle diameter represents the charge transfer resistance $\left(R_{\mathrm{ct}}\right){ }^{83,84}$
The capacitive performance was investigated through a chargedischarge behavior of $\mathrm{BiVO}_{4}$ surfaces, and also at the same region of $0.3 \mathrm{~cm}^{2}$ diameter, the applied currents were measured (Fig. 7b). $\mathrm{BiVO}_{4}$ electrodes were measured by separate, narrow potential windows between -1.0 to $-0.4 \mathrm{~V}$ and -0.3 to $0.1 \mathrm{~V}$. Due to the synergy between two components, the hybrid supercapacitorelectrode was working within the window of -1.0-0.1 V. Bismuth vanadate materials had significant increase in the voltage at levels above a certain point leading to significant variations of the linearity in their galvanostatic charge-discharge curves. The chargedischarge curves of $\mathrm{BiVO}_{4}$ were similar in shape to the equilateral triangles under high current conditions. ${ }^{89}$ During the charging and discharging process, linear curves show strong reversibility of the material. Furthermore, the charge-discharge curves of the hybrid supercapacitor at different currents kept a similar shape, indicating broad current range sustainability. The specific capacitance of modified electrodes was shown to be a more reliable candidate for supercapacitor devices, especially in the case of devices with minimal active materials. ${ }^{86,87}$

Current increase or decrease affects the specific capacity, but the flat plateau of the hybrid electrode compared to the $\mathrm{BiVO}_{4}$ electrode offered achievable rate improvements. The hybrid $\mathrm{BiVO}_{4}$ supercapacitor electrode's spatial capacitance increased until a saturation limit was achieved.

$$
\mathrm{SC}=\frac{I \times \Delta t}{\Delta V \times m} \mathrm{~F} \mathrm{~g}^{-1}
$$



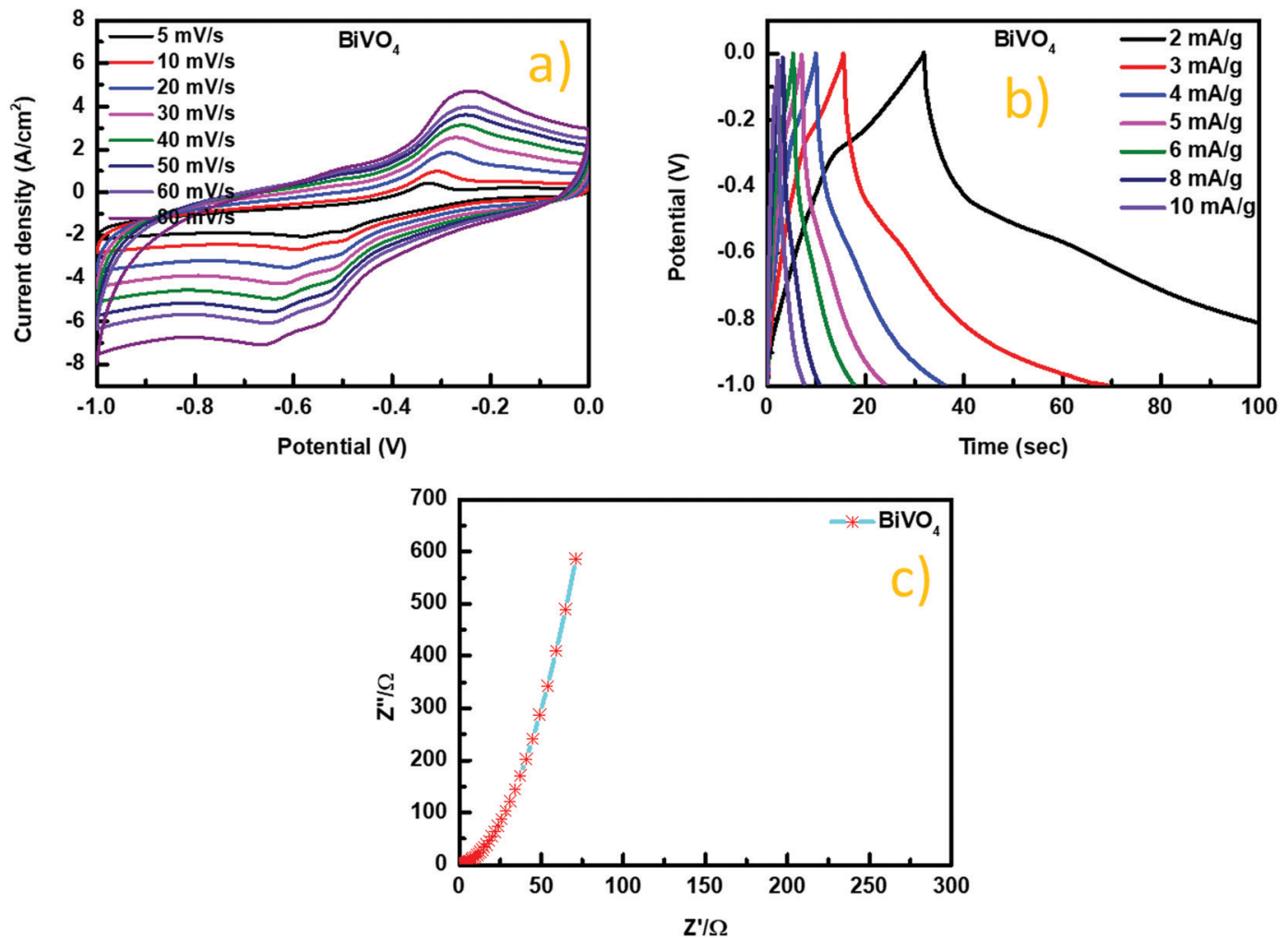

Fig. 7 (a) Cyclic voltammetry curves (b) charge-discharge curves (c) impedance spectra of $\mathrm{BiVO}_{4}$.

where $m$ is the mass of the electrode material $(g), V$ is the potential $(V), t$ is the discharge time $(s)$, and $I$ is the current density $(A)$. The plotted graph in Fig. 8a describes the relationship between the specific capacitance vs. current density of $\mathrm{BiVO}_{4}$. The $\mathrm{BiVO}_{4}$ microspheres exhibited a maximum specific capacitance of $1203 \mathrm{~F} \mathrm{~g}^{-1}$ at a current density of $2 \mathrm{~A} \mathrm{~g}^{-1}$. In addition, a decrease in the specific capacitance value was observed with an increase in the current density. The reduction in specific capacities at higher current densities could be due to the following reasons: (i) the faradaic reaction does not have

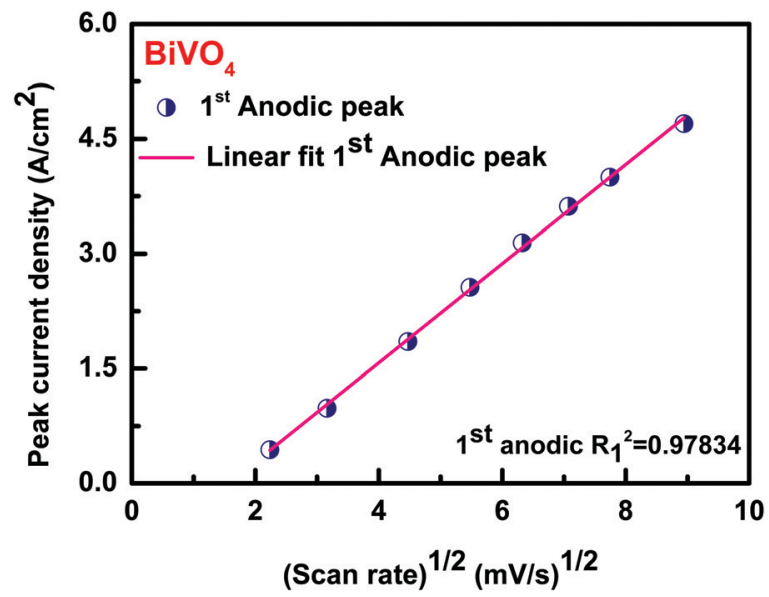

Fig. 8 Peak current density vs. square root of the scan rate plot of $\mathrm{BiVO}_{4}$. sufficient time, (ii) increase in ionic resistivity and (iii) decrease in charge diffusion to the inner active sites. ${ }^{88,89}$

Fig. 8 shows the relationship between peak current density vs. square root of the scan rate plot of $\mathrm{BiVO}_{4}$. The calculated plot visualized as linear with the correlation coefficient $\left(R^{2}\right)$ of 0.97834 for the 1 st anodic peak implies that the whole electrode reaction is controlled by the diffusion controlled-process. ${ }^{90-94}$ Fig. 9 shows the recycling stability test results under the current density of $2 \mathrm{Ag}^{-1}$. The specific capacitance values decreased during consecutive cycle runs. At around 2000 cycles, $75 \%$ of the specific capacitance value was retained. This value is higher than the typical $\mathrm{BiVO}_{4}$ material reported in the literature. ${ }^{64}$ The decrease in the cyclic stability of $75 \%$ could be due to the absence of the carbon additive. Among the known reported studies, the as-synthesized $\mathrm{BiVO}_{4}$ stands out as a better material.

\section{Conclusion}

Hierarchical $\mathrm{BiVO}_{4}$ was fabricated by a simple and one-step hydrothermal procedure. Such architectures have been designed with nanosheets that are highly orientated. The Ostwald's ripening mechanism played a key role in the growth design of 3D sheet composed architectures. The as-prepared hierarchical m-BiVO $4\left(1203 \mathrm{Fg}^{-1}\right)$ showed excellent electrochemical properties because of its smaller particle size and structure. This was ascribed to the full utilization of $\mathrm{m}-\mathrm{BiVO}_{4}$ and increased electrical conductivity and ionict ransfer. Notably, 


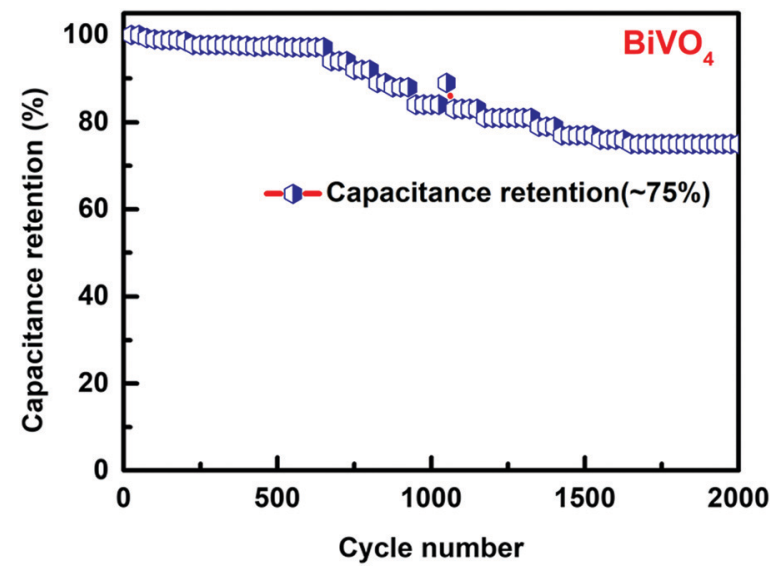

Fig. 9 Cyclic stability of $\mathrm{BiVO}_{4}$.

stable cycle capability was also achieved. Hence, $\mathrm{BiVO}_{4}$ is a promising candidate for superior supercapacitor fabrications. We foresee that our synthesis method to hierarchical m-BivO nanocomposites will be very beneficial for the development of solar cells and other energy storage devices.

\section{Conflicts of interest}

There are no conflicts to declare.

\section{Acknowledgements}

Dr Balachandran Subramanian is grateful for the financial support of the CAS President's International Fellowship Initiative (2016PM045) of China, the National Natural Science Foundation of China (51650110503 \& 51133009), and the National Basic Research Program of China (2012CB720304). Dr Karthikeyan Rajan is thankful for the National Natural Science Foundation of China (51871114).

\section{References}

1 L. Feng, S. Li, Y. Li, H. Li, L. Zhang, J. Zhai, Y. Song, B. Liu, L. Jiang and D. Zhu, Adv. Mater., 2002, 14, 1857-1860.

2 M. Choi, K. Na, J. Kim, Y. Sakamoto, O. Terasaki and R. Ryoo, Nature, 2009, 461, 246-249.

3 Y. Xiu, L. Zhu, D. W. Hess and C. P. Wong, Nano Lett., 2007, 7, 3388-3393.

4 R. Murugan and S. Ramakrishna, Compos. Sci. Technol., 2005, 65, 2385-2406.

5 S. Wu, X. Liu, T. Hu, P. K. Chu, J. P. Y. Ho, Y. L. Chan, K. W. K. Yeung, C. L. Chu, T. F. Hung, K. F. Huo, C. Y. Chung, W. W. Lu, K. M. C. Cheung and K. D. K. Luk, Nano Lett., 2008, 8, 3803-3808.

6 Y. L. Jung and H. J. Donahue, Tissue Eng., 2007, 13, 1879-1891.

7 V. L. Colvin, Nat. Biotechnol., 2003, 21, 1166-1171.

8 T. Dvir, B. P. Timko, D. S. Kohane and R. Langer, Nat. Nanotechnol., 2011, 6, 13-22.
9 G. Chen, G. T. McCandless, R. L. McCarley and S. A. Soper, Lab Chip, 2007, 7, 1424-1427.

10 S. Url, T. J. Archive and T. Archive, Science, 2007, 288, 1026-1029.

$11 \mathrm{H}$. Cao, J. O. Tegenfeldt, R. H. Austin and S. Y. Chou, Appl. Phys. Lett., 2002, 81, 3058-3060.

12 C. Ye, L. Zhang, X. Fang, Y. Wang, P. Yan and J. Zhao, Adv. Mater., 2004, 16, 1019-1023.

13 Y. T. Tseng, W. H. Tseng, C. H. Lin and R. M. Ho, Adv. Mater., 2007, 19, 3584-3588.

14 J. A. Rogers, M. Meier, A. Dodabalapur, E. J. Laskowski and M. A. Cappuzzo, Appl. Phys. Lett., 1999, 74, 3257-3259.

15 A. R. Parker and H. E. Townley, Nat. Nanotechnol., 2007, 2, 347-353.

16 J. Henzie, M. H. Lee and T. W. Odom, Nat. Nanotechnol., 2007, 2, 549-554.

17 Z. Li, Y. Ding, Y. Xiong, Q. Yang and Y. Xie, Chem. Commun., 2005, 918-920.

18 R. Srivastava, M. Choi and R. Ryoo, Chem. Commun., 2006, 4489-4491.

19 W. G. Bae, H. N. Kim, D. Kim, S. H. Park, H. E. Jeong and K. Y. Suh, Adv. Mater., 2014, 26, 675-700.

20 R. F. Service, Science, 2005, 309, 95.

$21 \mathrm{~W}$. Fischle, Y. Wang, C. D. Allis, C. Opin, C. Biol, J. A. Martens, F. Winston, C. Opin, G. Dev, M. M. Smith, C. Opin and C. Biol, Science, 2004, 303, 348-352.

22 T. D. Ewers, A. K. Sra, B. C. Norris, R. E. Cable, C. H. Cheng, D. F. Shantz and R. E. Schaak, Chem. Mater., 2005, 17, 514-520.

23 Y. Mao, M. Kanungo, T. Hemraj-benny and S. S. Wong, J. Phys. Chem. B, 2006, 110, 702-710.

24 X. Chen, X. Wang, Z. Wang, X. Yang and Y. Qian, Cryst. Growth Des., 2005, 5, 347-350.

25 L. S. Zhong, J. S. Hu, H. P. Liang, A. M. Cao, W. G. Song and L. J. Wan, Adv. Mater., 2006, 18, 2426-2431.

26 M. Mo, J. C. Yu, L. Zhang and S. K. A. Li, Adv. Mater., 2005, 17, 756-760.

27 L. Qu and L. Dai, J. Phys. Chem. B, 2005, 109, 13985-13990.

28 Z. Li, Y. Ding, Y. Xiong and Y. Xie, Cryst. Growth Des., 2005, 5, 1953-1958.

29 C. Jiang, W. Zhang, G. Zou, W. Yu and Y. Qian, J. Phys. Chem. B, 2005, 109, 1361-1363.

30 X. Gou, F. Cheng, Y. Shi, L. Zhang, S. Peng and J. Chen, J. Am. Chem. Soc., 2006, 128, 7222-7229.

31 Z. He, S. H. Yu, X. Zhou, X. Li and J. Qu, Adv. Funct. Mater., 2006, 16, 1105-1111.

32 N. Zhao and L. Qi, Adv. Mater., 2006, 18, 359-362.

33 Y. Huang, X. Duan and C. M. Lieber, Small, 2005, 1, 142-147.

34 R. Karthikeyan, M. Navaneethan, J. Archana, D. Thangaraju, M. Arivanandhan and Y. Hayakawa, Dalton Trans., 2014, 43, 17445-17452.

35 J. Zhang, S. Liu, J. Lin, H. Song, J. Luo, E. M. Elssfah, E. Ammar, Y. Huang, X. Ding, J. Gao, S. Qi and C. Tang, J. Phys. Chem. B, 2006, 110, 14249-14252.

36 C. Wang, D. Chen, X. Jiao and C. Chen, J. Phys. Chem. C, 2007, 111, 13398-13403. 
37 H. Shi, L. Qi, J. Ma and N. Wu, Adv. Funct. Mater., 2005, 15, 442-450.

38 Q. Gong, X. Qian, X. Ma and Z. Zhu, Cryst. Growth Des., 2006, 6, 1821-1825.

39 M. Conte, Fuel Cells, 2010, 10, 806-818.

40 G. Wang, L. Zhang and J. Zhang, Chem. Soc. Rev., 2012, 41, 797-828.

41 J. Su, L. Guo, S. Yoriya and C. A. Grimes, Cryst. Growth Des., 2010, 10, 856-861.

42 L. Zhang, D. Chen and X. Jiao, J. Phys. Chem. B, 2006, 110, 2668-2673.

43 W. Yin, W. Wang, L. Zhou, S. Sun and L. Zhang, J. Hazard. Mater., 2010, 173, 194-199.

44 H. Qing Jiang, H. Endo, H. Natori, M. Nagai and K. Kobayashi, J. Eur. Ceram. Soc., 2008, 28, 2955-2962.

45 L. Zhou, W. Wang, S. Liu, L. Zhang, H. Xu and W. Zhu, J. Mol. Catal. A: Chem., 2006, 252, 120-124.

46 C. Yu, S. Dong, J. Feng, J. Sun, L. Hu, Y. Li and J. Sun, Environ. Sci. Pollut. Res., 2014, 21, 2837-2845.

47 A. Zhang and J. Zhang, Spectrochim. Acta, Part A, 2009, 73, 336-341.

48 S. J. Hong, S. Lee, J. S. Jang and J. S. Lee, Energy Environ. Sci., 2011, 4, 1781-1787.

49 W. Yao, H. Iwai and J. Ye, J. Chem. Soc., Dalton Trans., 2008, 1426-1430.

50 M. Long, W. Cai and H. Kisch, J. Phys. Chem. C, 2008, 112, 548-554.

51 X. Zhang, Y. Gong, X. Dong, X. Zhang, C. Ma and F. Shi, Mater. Chem. Phys., 2012, 136, 472-476.

52 J. Su, L. Guo, N. Bao and C. A. Grimes, Nano Lett., 2011, 11, 1928-1933.

53 P. Ju, P. Wang, B. Li, H. Fan, S. Ai, D. Zhang and Y. Wang, Chem. Eng. J., 2014, 236, 430-437.

54 H. Seo, Y. Ping and G. Galli, Chem. Mater., 2018, 30, 7793-7802.

55 M. Han, X. Chen, T. Sun, O. K. Tan and M. S. Tse, CrystEngComm, 2011, 13, 6674-6679.

56 A. Kudo, K. Omori and H. Kato, J. Am. Chem. Soc., 1999, 121, 11459-11467.

57 M. S. S. Balachandran, N. Prakash, K. Thirumalai, M. Muruganandham and M. Sillanpaa, Ind. Eng. Chem. Res., 2014, 53, 8346-8355.

58 D. P. Dubal, K. Jayaramulu, R. Zboril, R. A. Fischer and P. Gomez-Romero, J. Mater. Chem. A, 2018, 6, 6096-6106.

59 S. Dutta, S. Pal and S. De, New J. Chem., 2018, 42, 10161-10166.

60 L. Deng, J. Liu, Z. Ma, G. Fan and Z. H. Liu, RSC Adv., 2018, 8, 24796-24804.

61 Z. Khan, S. Bhattu, S. Haram and D. Khushalani, RSC Adv., 2014, 4, 17378-17381.

62 S. S. Patil, D. P. Dubal, V. G. Deonikar, M. S. Tamboli, J. D. Ambekar, P. Gomez-Romero, S. S. Kolekar, B. B. Kale and D. R. Patil, ACS Appl. Mater. Interfaces, 2016, 8, 31602-31610.

63 A. Roy, P. Majumdar, P. Sengupta, S. Kundu, S. Shinde, A. Jha, K. Pramanik and H. Saha, Electrochim. Acta, 2020, 329, 135170.
64 C. Sengottaiyan, N. A. Kalam, R. Jayavel, R. G. Shrestha, T. Subramani, S. Sankar, J. P. Hill, L. K. Shrestha and K. Ariga, J. Solid State Chem., 2019, 269, 409-418.

65 R. Srinivasan, E. Elaiyappillai, S. Anandaraj, B. Kumar Duvaragan and P. M. Johnson, J. Electroanal. Chem., 2020, 861, 113972.

66 Z. J. Zhang, Q. C. Zheng and L. Sun, Ceram. Int., 2017, 43, 16217-16224.

67 C. Gai, F. Zhang, Q. Lang, T. Liu, N. Peng and Z. Liu, Appl. Catal., B, 2017, 204, 566-576.

68 M. Davis, C. Gümeci, C. Kiel and L. J. Hope-Weeks, J. Sol-Gel Sci. Technol., 2011, 58, 535-538.

69 Q. Fu, X. Wang, J. Zhou, J. Xia, Q. Zeng, D. Lv, C. Zhu, X. Wang, Y. Shen, X. Li, Y. Hua, F. Liu, Z. Shen, C. Jin and Z. Liu, Chem. Mater., 2018, 30, 4001-4007.

70 Y. Wen, Y. Zhao, M. Guo and Y. Xu, J. Mater. Sci., 2019, 54, 8236-8246.

71 L. Yan, W. Zhao and Z. Liu, Dalton Trans., 2016, 45, 11346-11352.

72 J. H. Pan, X. Zhang, A. J. Du, H. Bai, J. Ng and D. Sun, Phys. Chem. Chem. Phys., 2012, 14, 7481-7489.

73 Y. Qin, F. Zhang, Y. Chen, Y. Zhou, J. Li, A. Zhu, Y. Luo, Y. Tian and J. Yang, J. Phys. Chem. C, 2012, 116, 11994-12000.

74 J.-H. Lee, Sens. Actuators, B, 2009, 140, 319-336.

75 K. R. Tolod, S. Hernández, M. Castellino, F. A. Deorsola, E. Davarpanah and N. Russo, Int. J. Hydrogen Energy, 2020, 45, 605-618.

76 G. Silversmit, D. Depla, H. Poelman, G. B. Marin and R. De Gryse, J. Electron Spectrosc. Relat. Phenom., 2004, 135, 167-175.

77 M. D. Rossell, P. Agrawal, A. Borgschulte, C. Hébert, D. Passerone and R. Erni, Chem. Mater., 2015, 27, 3593-3600.

78 Y. Lu, Y. S. Luo, H. M. Xiao and S. Y. Fu, CrystEngComm, 2014, 16, 6059-6065.

79 A. Kudo, I. Tsuji and H. Kato, Chem. Commun., 2002, 1958-1959.

80 Z. He, Y. Shi, C. Gao, L. Wen, J. Chen and S. Song, J. Phys. Chem. C, 2014, 118, 389-398.

81 R. G. Pearson, Inorg. Chem., 1988, 27, 734-740.

82 W. Y. Changchang Maa, Jeongwoo Lee, Youjoong Kim, Won Cheol Seo and Hyun Jung, J. Colloid Interface Sci., 2020, 581, 514-523.

83 V. Vivier, A. Régis, G. Sagon, J. Y. Nedelec, L. T. Yu and C. Cachet-Vivier, Electrochim. Acta, 2001, 46, 907-914.

84 Y. C. Zhang, H. Yang, W. P. Wang, H. M. Zhang, R. S. Li, X. X. Wang and R. C. Yu, J. Alloys Compd., 2016, 684, 707-713.

85 V. D. Nithya, B. Hanitha, S. Surendran, D. Kalpana and R. Kalai, Selvan, Ultrason. Sonochem., 2015, 22, 300-310.

86 S. T. Senthilkumar, R. Kalai Selvan, M. Ulaganathan and J. S. Melo, Electrochim. Acta, 2014, 115, 518-524.

87 J. Liu, J. Jiang, M. Bosman and H. J. Fan, J. Mater. Chem., 2012, 22, 2419-2426.

88 C. Zhou, Y. Zhang, Y. Li and J. Liu, Nano Lett., 2013, 13, 2078-2085.

89 S. Yoon, E. Kang, J. Kon Kim, C. Wee Lee and J. Lee, Chem. Commun., 2011, 47, 1021-1023. 
90 Y. Gogotsi and P. Simon, Science, 2011, 334, 917-918.

91 W. W. Liu, Y. Q. Feng, X. Bin Yan, J. T. Chen and Q. J. Xue, Adv. Funct. Mater., 2013, 23, 4111-4122.

92 S. X. Wang, C. C. Jin and W. J. Qian, J. Alloys Compd., 2014, 615, 12-17.
93 Y. Tian, S. Cong, W. Su, H. Chen, Q. Li, F. Geng and Z. Zhao, Nano Lett., 2014, 14, 2150-2156.

94 S. Jayasubramaniyan, S. Balasundari, P. A. Rayjada, R. A. Kumar, N. Satyanarayana and P. Muralidharan, J. Mater. Sci.: Mater. Electron., 2018, 29, 21194-21204. 